\title{
Patruunoiden ja arkkitehdin yhteistyössä syntyivät metsäteollisuuden yhdyskunnat
}

\section{Aino Niskanen}

Johanna Björkman, Metsäteollisuuden jälki arkkitehtuurissa. Arkkitehti W.G. Palmqvistin ja yhtiöiden yhteistyö tehdasyhdyskunnissa 1920- ja 1930-luvulla (Helsingin yliopisto, 2019), 233 s. https://helda.helsinki.fi/handle/10138/300890

Johanna Björkmanin väitöskirja käsittelee ensisijaisesti metsäteollisuuden arkkitehtuuria, suunnitelmien tilaajien ja suunnittelijoiden vuorovaikutusta. Siinä käsitellään tärkeää ja vähän tutkittua aihetta, kuinka tilaajien, teollisuuspatruunoiden toiveet ja arkkitehdin näkemykset kohtasivat teollisuusalueiden suunnittelussa. Kirja keskittyy yhden arkkitehdin, W. G Palmqvistin ja häneltä suunnitelmia tilanneiden metsäteollisuuden yritysten väliseen yhteistyöhön maailmasotien välisenä aikana. Tänä ajanjaksona suomalainen teollisuus kasvoi erittäin nopeasti ja Suomeen syntyi merkittäviä teollisuusympäristöjä. Tehtaanjohtajien sosiaaliset verkostot ja sidokset, suh- teet ja neuvottelut arkkitehdin kanssa nousevat tarkastelun fokukseen.

Kyseessä on laaja, moniulotteinen kirja, perusteellisuudessaan välillä raskaskin mutta kokonaisuutena antoisa ja viimeistelty. Seitsemän päälukua voisi lukea myös erillisinä tietopaketteina. Tehdasyhdyskuntien rakentamishistoriaa koskeva luku nostaa esiin monia kansainvälisiä rinnastuksia ja esikuvia niin englantilaisista puutarhakaupunki-ideologiaan perustuvista mallikaupungeista kuin amerikkalaisista tai saksalaista tuotantolaitoksista ja -yhdyskunnista; Palmqvist matkusti tutustumassa moniin. Luvussa luonnehditaan lyhyesti myös metsäteollisuuden suomalaisia yrityksiä varhaisvaiheista alkaen. Teollisuusjohtajien ja arkkitehtien suhteille esitetään ruotsalaisia verrokkeja. Björkman kuvaa teollisuuspatruunoiden keskinäisiä verkostoja, joissa välitettiin kokemuksia niin matkoilta kun tehtailta.

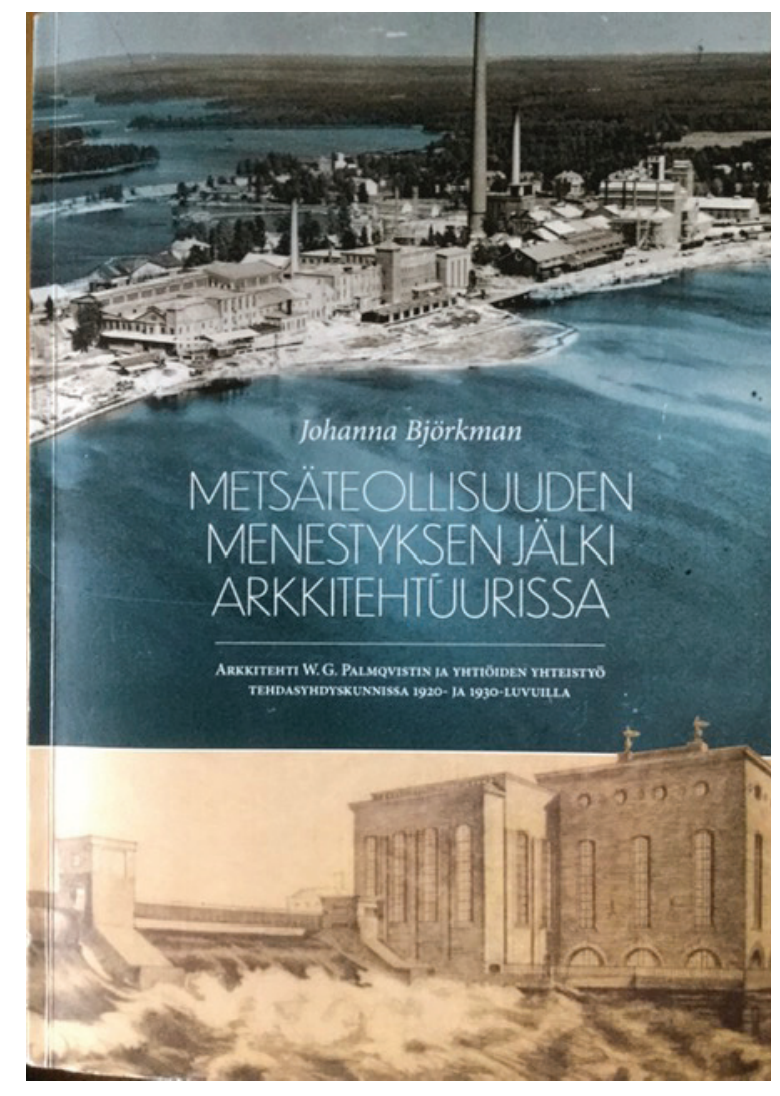

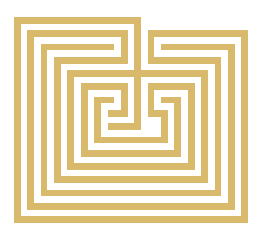


Palmqvistia käsittelevä kolmas luku on arkkitehdin elämäntyön kuvaus: opinnot, työura, tuotanto ja vaikutteet. Palmqvist on arkkitehtuurihistorioissa yleensä sivuutettu tyyliltään raskaana ja perinteisenä. Nyt nostetaan esiin, kuinka paljon hän piirsi sekä Helsingin keskustan liikerakennuksia, asuintaloja Töölöön, tuotantorakennuksia kirjapainoille ja Kaapelitehtaalle sekä tehdasyhdyskunnille ympäri maata; ei pelkästään asemakaavoja ja tuotantolaitoksia vaan seurataloja, kirkkoja, kouluja. Tyylillisiä vaikutteita hän tuntui hakeneen ennen muuta Saksasta. Juuri konservatiivisuutensa ja helppotajuisen tyylinsä ansioista hän oli pysynyt tilaajapiirien jatkuvassa suosiossa - näin kuvasi Palmqvistia Uuden Suomen 70-vuotiskirjoitus. Siinäpä arkkitehdin menestyksen avaimet vankan ammattitaidon lisäksi!

Kaksi seuraavaa lukua kuvaavat Palmqvistin suhdetta Gösta Serlachiukseen kehittämässä Mänttää sekä Rudolf Waldeniin piirtämässä Yhtyneiden Paperitehtaiden laitoksia ennen muuta Myllykoskella. G. A. Serlachiuksen edustama "hyvinvointikapitalismi" merkitsi yrityksen investointeja yhdyskunnan rakentamiseen ja sosiaalisen hyvinvointiin alkaen hierakkisesta asemakaavasta ja työväen kannustamisesta omaan rakentamiseen mallipiirustuksin. Yhteiskunnalliset jännitteet välähtelevät kerronnassa: 1905 ja 1906 lakot, 1917 levottomuudet - yritysjohdon eräänä vastauksena oli rakennuttaminen, yhdistelmä hyvinvoinnista huolehtimista ja kontrollia. Patruuna esimerkiksi paneutui intensiivisesti tehtaan kirkon suunnittelun yksityiskohtiin. Serlachius ilmaisi teollisuusyritysten velvollisuudeksi osallistua esteettisen arkkitehtuurin ja ympäristön luomiseen. Hän jopa osallistui suomalaisten johtohahmojen vetoomukseen talouselämälle rakennusten koristamiseksi taiteella eräänlainen prosenttitaiteen alkusysäys! Björkman on onnistunut jäljittämään kirjeenvaihtoa ja keskusteluja tilaajan ja suunnittelijoiden välillä. Palmqvist menestyi hyvin kommunikoinnissa Serlachiuksen kanssa, kun oli altis taipumaan tämän toiveisiin. Näin oli myös suhteessa voimakastahtoiseen Rudolf Waldeniin, jolle Palmqvist suunitteli yli 20 vuotta. Myllykosken mahtavaa paperitehdasta Björkman erittelee huolella, nostaen esiin detaljit, joihin arkkitehti oli paneutunut tehtaan sisätiloissa.

Viimeiset, osin yhteenvedonomaiset tarkastelevat edelleen tilaajien ja suunnittelijoiden suhteita. Mainitut kaksi metsäteollisuuden johtajaa tukeutuivat pyrkimyksissään ympäristöjen parantamiseen englantilaiseen puutarhakaupunki-ideologiaan ja Camillo Sitten kaupunkisuunnitteluihanteisiin. Samoja vaikutteita oli nähdäkseni reformistisissa 1920-luvun asuntoalueissa kuten Helsingin Vallilassa ja Puu-Käpylässä. Näiden teollisuuspaik- kakuntien ilme muodostui kuitenkin erilaiseksi patruunoiden suunnittelijavalintojen ja ympäristön hierarkisoinnin myötä. Kiintoisa löytö on traditionaalista arkkitehtuuria suosineen Serlachiuksen kääntyminen Alvar Aallon puoleen hakiessaan Oulun Toppilan tehtaan suunnittelijaa - Palmqvistin ilmeisestä närkästyksestä huolimatta. 1930-luvun mittaan Serlachius taipui kannattamaan modernismia. Yhtyneiden Paperitehtaiden osallisuus Sunila-hankkeeseen toi sitten Waldeninkin kosketuksiin modernismin kanssa.

Kuvattujen yritysten osin holhoava puuttuminen tehtaalaisten asumisympäristöihin tuntuu vieraalta nykyajan näkökulmasta. Siihen liittynyttä yhteiskuntavastuun ideologiaa voisimme kuitenkin kaivata tänään. Mänttä ja Myllykoski ovat osa kansalista rakennusperintöä ja vaativat vaalimista niiden käyttötapojenkin muututtua.

Helpolla ei Björkman ole itseään päästänyt. Vastaväittäjä, apulaisprofessori Anna Sivulan sanoin "työssä avataan arkkitehtuurin ja metsäteollisuuden vuoropuhelua tehdasyhdyskunnan arkkitehtuuriin sisältyvää diskursiivista valtaa, tilaajien esteettisiä näkemyksiä, sekä teollisuusarkkitehtuurin, teollisuusrakentamisen ja tehdasyhdyskuntien ilmentämän hyvinvointikapitalismin kulttuurihistoriaa."1 Työläs ratkaisu, mutta antoisa kokonaisuus. Kirja on runsaasti kuvitettu ja miellyttävästi taitettu. 
1 Anna Sivula, esitarkastuslausunto Johanna Björkmanin väitöskirjan käsikirjoitukseen, 9.11.2018.

Arkkitehti, TkT Aino Niskanen toimi TKK:n/Aalto-yliopiston vakituisena arkkitehtuurin historian professorina 2007-2018.

Väitöskirja Väinö Vähäkalliosta kuvasi arkkitehdin uran rakentumista 1910-luvulta 50-luvulle. Osuusliike rakentaa -kirja käsitteli suomalaisen osuustoiminnan arkkitehtuuria. Hän on kirjoittanut Uno Ullbergista, Alvar Aallosta ja Reima Pietilästä sekä suomalaisen modernismin eri näkökulmista. 